\title{
Pengaruh Covid-19 Terhadap Proses Pembelajaran Daring di Yayasan Pendidikan Cawan Bethel
}

\author{
Witarsa Tambunan ${ }^{1}$, Hotner Tampubolon², Dameria Sinaga ${ }^{3}$, Lisa Gracia Kailola ${ }^{4}$ \\ 1, 2, 3,4 Universitas Kristen Indonesia, Jakarta , Indonesia \\ E-mail: witarsa.oke@gmail.com; hotnertampubolon@yahoo.com; dr dameria sinaga@yahoo.com; \\ lisa.gracia@uki.ac.id
}

\begin{abstract}
ABSTRAK
Kegiatan Pengabdian Kepada Masyarakat (PKM) yang diadakan oleh Dosen Program Study Manajemen Pendidikan Pascasarjana di Yayasan Pendidikan Cawan mensosialisasikan alternatif pembelajaran penggunaan daring pada masa pandemic covid 19. Tujuan penelitian ini untuk 1).Membuktikan Ketidak siapan Sekolah Melaksanakan Pembelajaran Daring, 2). Membantu Keterbatasan Sarana Dan Prasarana di Yayasan Pendidikan Cawan, 3). Meningkatkan penguasaan Tekonologi Tinggi guru di Yayasan Pendidikan Cawan, 4). Membangun Jaringan Internet Kurang Memadai di Yayasan Pendidikan Cawan, 5). Meningkatkan Gadget yang dimiliki siswa di Yayasan Pendidikan Cawan. Penelitian ini menggunakan metode kualitatif sebab akibat (causalitatif) dengan pendekatan Pohon Masalah, Pohon Sasaran dan Pohon Alternatif . Hasilnya : 1). Ternyata Pandemic covid -19 memaksa guru-guru di Yayasan Pendidikan Cawan untuk dapat menggunakan teknologi dalam proses pembelajaran, 2.)Ternyata Kemampuan guru dalam menggunakan tekonologi pada proses pembelajaran merupakan salah satu indikator kesiapan sekolah dalam melaksanakan pembelajaran daring, 3). Ternyata Inovasi dan kreativitas dalam menggunakan media teknologi sebagai media pembelajaran menjadi hal yang mutlak diperlukan di era globalisasi, khususnya di masa pandemic saat ini, 4).Ternyata Pemberdayaan guru melalui berbagai pelatihan penggunaan teknologi, informasi dan computer yang ada dapat membantu guru untuk meningkatkan kemampuan dasarnya sehingga dapat menggunakan teknologi dalam pembelajaran.
\end{abstract}

Kata kunci : Pembelajaran Daring, Pandemic Covid 19 , Pemberdayaan Guru.

\begin{abstract}
Community Service Activities (PKM) held by Lecturers of the Postgraduate Education Management Study Program at the Cawan Education Foundation to socialize alternative learning to use online during the Covid 19 pandemic. The objectives of this study are to: 1). Proving School Unpreparedness to Implement Online Learning. 2). Helping the Limited Facilities and Infrastructure at the Cawan Education Foundation, 3). Increasing mastery of Higher Technology teachers at the Cawan Education Foundation, 4). Building an Inadequate Internet Network at the Cawan Education Foundation, 5). Improving the Gadgets that students have at the Cawan Education Foundation, This study uses a qualitative method of cause and effect (causalitative) with the approach of the Problem Tree, Target Tree, and Alternative Tree. The result: 1). It turns out that the Covid-19 pandemic forces teachers at the Cawan Education Foundation to be able to use technology in the learning process, 2). It turns out that the teacher's ability to use technology in the learning process is an indicator of school readiness in implementing online learning, 3). It turns out that innovation and creativity in using technology media as a medium of learning are absolutely necessary in the era of globalization, especially in the current pandemic, 4). It turns out that the empowerment of teachers through various training on the use of existing technology, information
\end{abstract}


and computers can help teachers to improve their basic abilities so that they can use technology in learning.

Keywords: Online Learning, Pandemic Covid 19, Teacher Empowerment.

\section{PENDAHULUAN}

Pada masa pandemi Covid 19 (2020-2021) saat ini , semua elemen penyelenggara pendidikan merasakan dampaknya. Dunia pendidikan terguncang atau bisa dikatakan bingung untuk menyikapi bagaimana caranya mengatasi agar proses belajarmengajar berjalan sebagaimana kurikulum yang telah ditetapkan .Guru dan Sekolah dalam menyikapi perubahan yang demikian cepat tanpa dapat menemukan metode yang cocok/sesuai. Sehingga guru mau tidak mau, siap tidak siap harus merancang pengembangan pembelajaran. Pengembangan pembelajaran dimaksud adalah bersifat kontekstual. Pembelajaran kontekstual maksudnya perancangan dan pengembangan pembelajaran disesuiakan dengan keadaan dan pada daerah dan kearipan lokal yang tersedia. Dengan demikian peningkatan kualitas SDM ini harus segera disikapi oleh penyelenggara pedidikan . Peningkatan kualitas SDM melalui jalur pendidikan formal mulai dari tingkat satuan pendidikan dasar (SD, SMP) dan menengah (SMA, SMK) hingga ke perguruan tinggi adalah kunci untuk mampu mengikuti perkembangan Revolusi Industri 4.0. Guru memiliki peran yang sangat strategis dalam menyiapkan kompetensi peserta didik dalam pembelajaran di sekolah dengan menggunakan model pembelajaran yang tepat agar peserta didik mampu berpikir kritis dan kreatif sesuai dengan tingkat satuan pendidikan.

Keberhasilan untuk menghadapi masa pandemik tergantung beberapa variable antara lain penguasaan IPTEK dan kualitas guru. Guru dituntut menguasai kompetensi sebagai pendidik, yakni kompetensi pedagogik, kompetensi personal, kompetensi interpersonal dan kompetensi profesional (UU No. 14 tahun 2015). Peraturan Pemerintah No. 74 tahun 2008 tentang Guru, pasal 3 ayat 2, seorang guru dikatakan profesional apabila memenuhi beberapa kriteria atau persyaratan kompetensi yang meliputi kompetensi pedagogik, kompetensi kepribadian, kompetensi sosial, dan kompetensi professional. Pada sisi lain, keadaan ini memunculkan berbagai permasalahan dalam yang dialami peserta didik, pendidik, dan orang tua/wali dalam pembelajaran online. Oleh karena itu, peserta didik, pendidik, dan orang tua/wali diharapkan bersinergi dalam upaya optimalisasi pengelolaan pembelajaran online. (I Made Ari Winangun, 2020). Pembelajaran online ini tentu merupakan tantangan baru bagi tenaga guru yang membuat mereka harus menguasai media pembelajaran online untuk melangsungkan kegiatan pembelajaran dan diharapkan mampu berkreasi dalam proses 
pembelajaran supaya tujuan pembelajaran dapat dicapai secara maksimal (Mantra, 2020).

Peraturan Menteri Pendidikan Nasional nomor 16 Tahun 2007 mengatur kompetensi guru untuk setiap satuan pendidikan mencakup kualifikasi akademik guru pendidikan Anak Usia Dini/Taman Kanak-kanak/Raudatul Atfal (PAUD/TK/RA), guru sekolah dasar/madrasah ibtidaiyah (SD/MI), guru sekolah menengah pertama/madrasah Tsanawiyah (SMP/MTs), guru sekolah menengah atas/madrasah aliyah (SMA/MA). Pemerintah sudah dan terus berupaya agar SDM mampu menghadapi kemajuan yang sangat cepat diantaranya dengan mengeluarkan kebijakan pada tahun TA 2019/2020 agar sekolah mengimplementasikan Kurikulum 2013 baik sekolah yang diselenggarakan pemerintah maupun sekolah yang diselenggarakan oleh masyarakat atau yayasan.

Surat Edaran Menteri Pendidikan dan Kebudayaan Republik Indonesia Nomor 4 Tahun 2020 Tentang Pelaksanaan Kebijakan Pendidikan Dalam Masa Darurat Penyebaran Coronavirus Disease (Covid-19) poin ke 2 yaitu proses belajar dari rumah dilaksanakan dengan ketentuan sebagai berikut :

a. Belajar dari rumah melalui pembelajaran daring/jarak jauh dilaksanakan untuk memberikan pengalaman belajar yang bermakna bagi siswa, tanpa terbebani tuntutan menuntaskan seluruh capaian kurikulum untuk kenaikan kelas maupun kelulusan;

b. Belajar dari rumah dapat difokuskan pada pendidikan kecakapan hidup antara lain mengenai pandemic Covid19;

c. Aktivitas dan tugas pembelajaran belajar dari rumah dapat bervariasi antarsiswa, sesuai minat dan kondisi masing-masng, termasuk mempertimbangkan kesenjangan akses/fasilitas belajar dirumah;

d. Bukti atau prosuk aktivitas belajar dari rumah diberi umpan balik yang bersifat kualitatif fan berguna dari guru, tanpa diharuskan memberi skor/nilai kuantitatif.

Setiap lembaga pendidikan harus mempersiapkan orientasi dan rancangan dalam bidang pendidikan, terutama yang sangat terkait erat dengan persiapan SDM dalam hal ini adalah guru. Pada PKM Prodi Administrasi/ Manajemen Pendidikan Universitas Kristen Indonesia merancang sebuh penyuluhan tentang kebijakan pendidikan secara online pada masa pandemik Covis 19 ini. Adapun sasaran dalam PKM ini adalah para guru guru di TK, SD,SMP,SMK dan SMA Sekolah Yayasan Cawan Betel Jakarta . PKM ini dilaksanakan sebagai tindak lanjut dari Perjanjian Kerja sama antara Pascasarjana UKI dengan Yayasan Cawan Betel sebagai penyelenggara pendidikanTK, SD , SMP , SMA dan SMK. 


\section{METODE}

Metode yang digunakan dalam kegiatan Program PkM ini dilaksanakan dengan tahapan sebagai berikut: 1) Studi awal dengan metode FGD dosen Prodi Administrasi/Manajemen Pendidikan dengan guru TK,SD,SMP,SMK dan SMA Yayasan Cawan Betel melalui Webinar. Data diperoleh dengan diskusi mendalam terhadap guru-guru Yayasan tersebut, 2) Melakukan dan menyusun rancangan program yang sesuai dengan kebutuhan sekolah dan relevan dengan bidang ilmu Prodi Administrasi/Manajemen pendidikan. 3) Melakukan penyuluhan tentang Kebijakan pendidikan baik regulasi pemerintah maupun pada unit pendidikan, 4) Melakukan evaluasi pelatihan dan dampak bagi sekolah dan dijadikan dasar dalam melakukan pelatihan secara berkelanjutan.

\section{HASIL DAN PEMBAHASAN}

Program PKM ini merupakan hasil penelitian yang dilakukan oleh peneliti di Yayasan Pendidikan Cawan Betel Jakarta. Hasil penelitian ini diabdikan kepada Sekolah Yayasan Cawan Betel pada kegiatan penyuluhan tentang alternatif pembelajaran kontekstual pada masa pandemic covid 19.

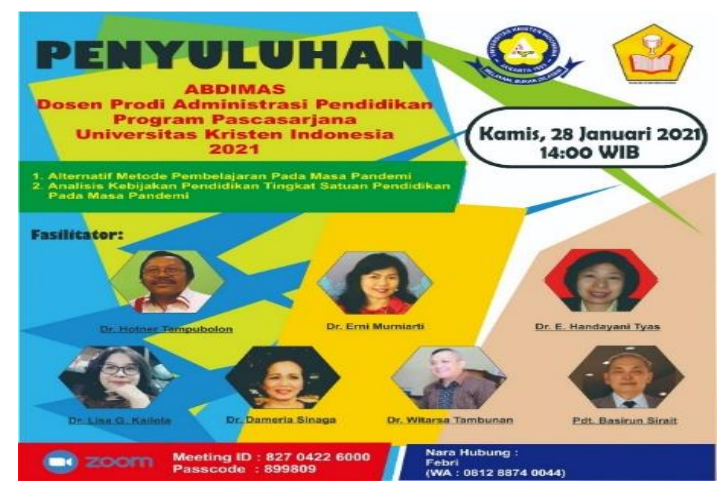

Kegiatan Pengabdian kepada Masyarakat (Dosen Program Study Administrasi /Manajemen Pendidikan Pascasajana Universitas Kristen Indonesia (UKI), pada tanggal 28 Januari 2021 di Sekolah Yayasan Pendidikan Cawan Betel membina Sekolah TK, SD , SMP , SMA dan SMK.

Analisis kebijakan Pendidikan merupakan cara memecahkan masalah yang ada dalam kebijakan - kebijakan tentang Pendidikan menggunakan pemahaman yang dimiliki oleh manusia sendiri. Mendikbud Nadiem Makarim mempunyai 10 Kebijakan Pendidikan yakni:

1. Menerapkan kolaborasi dan pembinaan antar sekolah (TK - SD SMP - SMA, informal)

2. Meningkatkan kualitas guru dan kepala sekolah

3. Membangun platform pendidikan nasional berbasis teknologi

4. Memperbaiki kurikulum nasional, pedagogi, dan penilaian

5. Meningkatkan kolaborasi dengan pemerintah daerah untuk memastikan distribusi yang merata.

6. Membangun sekolah / lingkungan belajar masa depan.

7. Memberikan insentif atas kontribusi dan kolaborasi pihak swasta di bidang Pendidikan.

8. Mendorong kepemilikan industri dan otonomi pendidikan vokasi.

9. Membentuk pendidikan tinggi kelas dunia. 
10. Menyederhanakan mekanisme akreditasi dan memberikan otonomi lebih .

Pembelajaran di rumah menuntut guru untuk menyediakan bahan ajar dan memanfaatkan sistem infomasi online untuk menyampaikan proses pembelajaran. Media online digunakan sebagai ruang pembelajaran untuk membagikan bahan ajar, memberikan tugastugas belajar siswa dan memonitoring pelaksanaan pembelajaran online yang dilaksanakan siswa. Melalui online learning atau pembelajaran berbasis daring, siswa dapat mempelajari bahan ajar dan mengerjakan tugas-tugas yang diberikan guru selama berada di rumah. Pembelajaran di rumah dengan metode daring ternyata tidak dapat dengan mudah diterapkan di Yayasan Pendidikan Cawan. Salah satu pokok masalah dalam masa pendemic Covid-19 yang dihadapi Yayasan Pendidikan Cawan adalah ketidaksiapan sekolah dalam melaksanakan pembelajaran daring.

\section{SIMPULAN}

1. Ternyata Pandemic covid -19 memaksa guru-guru di Yayasan Pendidikan Cawan untuk dapat menggunakan teknologi dalam proses pembelajaran.

2. Ternyata Kemampuan guru dalam menggunakan tekonologi pada proses pembelajaran merupakan salah satu indikator kesiapan sekolah dalam melaksanakan pembelajaran daring.

3. Ternyata Inovasi dan kreativitas dalam menggunakan media teknologi sebagai media pembelajaran menjadi hal yang mutlak diperlukan di era globalisasi, khususnya di masa pandemic saat ini.

4. Ternyata Pemberdayaan guru melalui berbagai pelatihan penggunaan teknologi, informasi dan computer yang ada dapat membantu guru untuk meningkatkan kemampuan dasarnya sehingga dapat menggunakan teknologi dalam pembelajaran.

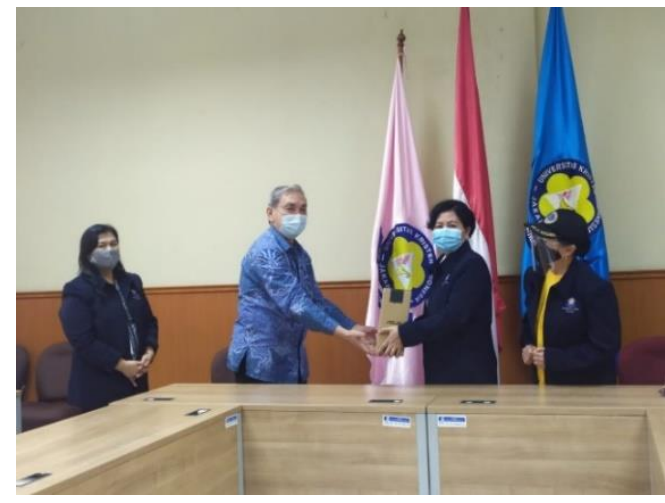

\section{UCAPAN TERIMA KASIH}

Dengan telah terlaksananya Abdimas dosen Prodi Administrasi/Manajemen Pendidikan PPS UKI priode tahun 20192020, kami dari Tim PKM dengan kerendahan hati menyampaikan ucapan terima kasih kepada :

1. Rektor UKI Bapak Dr. Dhaniswara Kharjono,SH, MH, MBA sebagai afiliasi penulis dan sebagai pimpinan Universitas.

2. Direktur PPS UKI Ibu. Dr. Bintang Simbolon dan Kaprodi Administrasi/ Manajemen Pendidikan Ibu.Dr.Mesta Limbong yang telah mendorong penulis untuk memberikan penyuluhan dengan materi tentang alternatif pembelajaran 
kontekstual pada masa pandemic covid 19 . Sebagai hasil penelitian yang di abdimaskan kepada Sekolah Yayasan Cawan Betel Jakarta.

3. Ketua LPPM UKI yang telah memfasilitasi kepada penulis untuk melakukan salah satu dari Tridarma Perguruan Tinggi yakni Abdimas di Sekolah Yayasan Cawan Betel Jakarta.

4. Pimpinan /Pengurus Yayasan Cawan Betel dan Guru-guru TK,SD,SMP,SMA dan SMK Sekolah Yayasan Cawan Betel Jakarta.

\section{REFERENSI}

Mabes RI (2020). Buku Pedoman Polri Menghadapi Covid-19. Diakses pada 21 Mei 2020 dari https://books.google.co.id/books?id=W $\underline{\text { nLcDwAAQBAJ\&pg=PA7\&dq=covid }+1}$ 9\&hl=id\&sa $=X \# v=$ onepage $\& \mathrm{q}=$ covid $\%$ 2019\&f=false

Medico, D. B. (2020). Coronavirus Covid19, Membela Diri, Cara Menghindari Penularan, Bagaimana Melindungi Keluarga Dan Pekerjaan Anda. Bruno Del Medico Editor.

Priangan, K. (2020). Dampak Pandemi Covid19 Terhadap Dunia Pendidikan.
Sianipar, D., Rambitan, S., Sairwona, W., \& Zega, Y. K. (2020). Pelatihan Penggunaan Metode Mengajar Remaja Di Masa Pandemi Covid-19 Di Hkbp Resort Jatisampurna Bekasi. JURNAL ComunitÃ Servizio: Jurnal Terkait Kegiatan Pengabdian kepada Masyarakat, terkhusus bidang Teknologi, Kewirausahaan dan Sosial Kemasyarakatan, 2(2), 406-428.

Sormin, E., Harefa, N., Sitompul, F., Arodes, E. S., Cing, J. M., Tehupeiory, A., ... \& Azzahra, S. F. (2020). Aksi Uki Perduli Dalam Rangka Pencegahan Penyebaran Virus Covid-19. JURNAL ComunitÃ Servizio: Jurnal Terkait Kegiatan Pengabdian kepada Masyarakat, terkhusus bidang Teknologi, Kewirausahaan dan Sosial Kemasyarakatan, 2(2), 471-478.

Suardi, M. (2018). Belajar \& pembelajaran. Deepublish.

Tambunan, W. (2020). 65 Tahun Hidup Dalam Kebhinekaan: Pandangan Kritis Dari Sisi Pendidikan Politik. 